\title{
Efektivitas Tindakan Skeling terhadap Perawatan Gingivitis di Rumah Sakit Gigi dan Mulut Universitas Sam Ratulangi Manado
}

\author{
${ }^{1}$ Febri Korompot \\ ${ }^{1}$ Krista V. Siagian \\ ${ }^{2}$ Damajanty H. C. Pangemanan \\ ${ }^{1}$ Johanna Khoman
}

\author{
${ }^{1}$ Program Studi Pendidikan Dokter Gigi Fakultas Kedokteran \\ ${ }^{2}$ Bagian Fisiologi Fakultas Kedokteran \\ Universitas Sam Ratulangi Manado \\ Email: ebhykorompot@gmail.com
}

\begin{abstract}
The most common periodontal disease is gingivitis which is caused by biofilm accumulation on plaque around the gingival margin and inflammatory response to bacteria. Scaling is used to eliminate bacterial and calculus deposits that cause gingivitis. This study was aimed to determine the effectiveness of scaling in gingivitis treatment. This was a preexperimental study with one group pre and post test design. Samples were obtained by using total sampling technique. There were 30 patients aged 17-45 years that had scaling performed on them at RSGM in 2019. Gingivitis was observed before and after scaling using the modified gingival index (MGI). The results showed that before scaling, there were mild gingivitis $23.30 \%$, moderate gingivitis $70 \%$, and severe gingivitis $6.70 \%$. Two days after scaling, mild gingivitis and moderate gingivitis were observed $50 \%$ each. The paired sample ttest showed a p-value of 0.000 . In conclusion, scaling is effective in gingivitis treatment based on the assessment using the modified gingival index.
\end{abstract}

Keywords: gingivitis, scaling, modified gingival index

\begin{abstract}
Abstrak: Penyakit periodontal yang paling sering dijumpai yakni gingivitis (peradangan gingiva). Gingivitis disebabkan oleh akumulasi biofilm pada plak di sekitar margin gingiva dan respon peradangan terhadap bakteri. Tindakan untuk menghilangkan deposit bakteri dan kalkulus yang menyebabkan gingivitis salah satunya ialah tindakan skeling. Tujuan penelitian ini untuk mengetahui efektivitas tindakan skeling terhadap perawatan gingivitis. Jenis penelitian ialah pra eksperimental dengan one grup pre and post test design. Pengambilan sampel menggunakan teknik total sampling terhadap pasien yang berusia 17-45 tahun yang dilakukan tindakan skeling di RSGM pada tahun 2019 berjumlah 30 orang. Penelitian ini dilakukan dengan melihat gingivitis sebelum skeling dan setelah skeling melalui pengukuran keparahan gingiva menggunakan modified gingival index (MGI). Hasil penelitian menunjukkan bahwa sebelum skeling gingivitis ringan 23,30\%, gingivitis sedang $70 \%$, gingivitis berat $6,70 \%$. Dua hari pasca skeling didapatkan gingivitis ringan dan gingivitis sedang sama besar yaitu masing-masing $50 \%$. Hasil uji t berpasangan menunjukkan nilai $\mathrm{p}=0,000$. Simpulan penelitian ialah tindakan skeling efektif terhadap perawatan gingivitis berdasarkan penilaian modified gingival index.
\end{abstract}

Kata kunci: gingivitis, skeling, modified gingival index

Penyakit periodontal merupakan penyakit peradangan pada jaringan sekitar gigi yang berawal dari inflamasi gingiva dan berlanjut ke kerusakan struktur jaringan penyangga gigi lainnya, seperti sementum, jaringan periodontal, dan tulang alveolar. 
Penyebab utama penyakit periodontal yaitu plak bakteri dan kalkulus yang terakumulasi pada permukaan gigi. ${ }^{2,3}$ Penyakit periodontal merupakan salah satu penyakit gigi dan mulut yang masih sering didapatkan pada masyarakat Indonesia. ${ }^{4}$

Berdasarkan data Riset Kesehatan Dasar (Riskesdas) tahun 2013 prevalensi masalah kesehatan gigi dan mulut di Indonesia sebesar $25,9 \%,{ }^{5}$ sementara itu Riskesdas tahun 2018 menunjukkan adanya peningkatan prevalensi menjadi $57,6 \%{ }^{6}$ Penyakit periodontal memiliki prevalensi cukup tinggi, banyak diderita oleh hampir seluruh manusia di dunia dan mencapai $50 \%$ dari jumlah populasi dewasa. ${ }^{7}$ Penyakit periodontal yang paling sering dijumpai yakni peradangan gingiva atau gingivitis.

Gingivitis merupakan reaksi inflamasi dari gingiva yang ditandai dengan perubahan warna, perdarahan, adanya pembengkakan, dan lesi pada gingiva. Gingivitis sering terjadi baik pada anak maupun dewasa. Gingivitis pada anak atau puberty gingivitis terjadi karena adanya peningkatan hormon endokrin yang biasa terjadi pada anak di bawah usia 17 tahun atau selama masa remaja, ${ }^{8}$ sedangkan gingivitis pada dewasa biasanya disebabkan oleh akumulasi biofilm pada plak di sekitar margin gingiva dan respon peradangan terhadap bakteri. Plak yang tidak dibersihkan dari lapisan luar gigi akan menjadi tempat berkumpulnya bakteri. Bakteri tersebut akan mengeluarkan zat yang bersifat asam dan dapat merusak gingiva. Di samping itu bakteri mendukung perubahan plak yang tidak dibersihkan sehingga akan menjadi karang gigi atau kalkulus. ${ }^{9}$

Tindakan untuk menghilangkan deposit bakteri dan kalkulus yang menyebabkan gingivitis salah satunya ialah tindakan skeling. Tindakan ini dikombinasikan dengan selalu memperhatikan kebersihan gigi dan mulut pasien, merupakan bentuk perawatan dasar yang efektif dalam merawat gingivitis yang diinduksi oleh plak dan kalkulus. Diharapkan pasca tindakan skeling akan terjadi proses penyembuhan berupa hilangnya peradangan dalam jarringan ikat gingiva. ${ }^{7,10}$

Rumah Sakit Gigi dan Mulut Universitas Sam Ratulangi (RSGM Unsrat) merup-akan satu-satunya rumah sakit gigi dan mulut yang ada di kota Manado yang terletak di J1. Dr. Sutomo nomor 3, Kelurahan Pinaesaan, Kecamatan Wenang. Rumah sakit tersebut terdiri atas empat lantai dan memiliki beberapa pelayanan kesehatan gigi dan mulut, salah satunya yaitu tindakan skeling. Berdasarkan uraian tersebut, maka penulis tertarik untuk meneliti efektivitas tindakan skeling terhadap perawatan gingivitis pada pasien di Rumah Sakit Gigi dan Mulut Universitas Sam Ratulangi Manado.

\section{METODE PENELITIAN}

Jenis penelitian yang dilakukan ialah quasi experimental dengan pendekatan one grup pre and post test design. Penelitian dilaksanakan pada bulan Mei 2019 di Rumah Sakit Gigi dan Mulut Universitas Sam Ratulangi Manado. Populasi penelitian ini yaitu pasien yang melakukan tindakan skeling ultrasonik di Bagian Periodonsia Rumah Sakit Gigi dan Mulut Universitas Sam Ratulangi. Metode pengambilan sampel yang digunakan ialah total sampling terahadap yang memenuhi kriteria inklusi berjumlah 30 orang.

Tindakan skeling yang dimaksud dalam penelitian ini yaitu prosedur pembuangan plak bakteri dan kalkulus pada subgingiva dan supragingival dengan menggunakan skeling ultrasonik.

Gingivitis yang dimaksud pada penelitian ini ialah gingivitis yang ditandai dengan adanya perubahan warna gingiva dari warna normal (merah muda) ke warna inflamasi (merah atau merah kebiruan), adanya pembengkakan pada gingiva, adanya lesi pada gingiva, gingiva mudah berdarah, dan yang sudah didiagnosis oleh operator. Penilaian dilakukan menggunakan modified gingival index (MGI). Pemeriksaan dilaku-kan pada gigi 16 sisi bukal, 11 sisi labial, 26 sisi bukal, 36 sisi lingual, 31 sisi labial, dan 46 sisi lingual. Selanjutnya dijumlahkan dan dibagi jumlah indeks gigi yang diambil dikali 
jumlah permukaan yang diperiksa dan didapatkan skor indeks gingiva sese-orang. Jumlah skor semua gigi yang diperiksa dibagi dengan jumlah gigi yang diperiksa maka diperoleh skor MGI.

Tabel 1. Kriteria gingiva untuk modified gingival index ${ }^{11}$

\begin{tabular}{ll}
\hline Skor & Keadaan gingiva \\
\hline 0 & Tidak ada inflamasi \\
1 & Inflamasi ringan 1: sedikit \\
& perubahan warna dan sedikit \\
perubahan tekstur pada seluruh \\
permukaan, tetapi tidak \\
mencakup bagian marginal atau \\
papila gingiva \\
Inflamasi ringan 2: sedikit \\
perubahan warna dan tekstur \\
yang meliputi semua \\
permukaan, termasuk bagian \\
marginal atau papila gingiva \\
Inflamasi sedang: permukaan \\
mengkilat, kemerahan, edema, \\
dan atau hipertrofi pada \\
marginal atau papila gingiva \\
Inflamasi parah: tanda \\
kemerahan, edema, dan atau \\
hipertrofi pada marginal atau \\
papila gingiva; perdarahan \\
spontan, ulserasi
\end{tabular}

Tabel 2. Indeks gingiva ${ }^{11}$

\begin{tabular}{cl}
\hline Skor & Kriteria \\
\hline $0,1-1,0$ & Gingivitis ringan \\
$1,1-2,0$ & Gingivitis sedang \\
$2,1-3,0$ & Gingivitis parah \\
\hline
\end{tabular}

Instrumen, alat dan bahan penelitian yang digunakan dalam penelitian ini ialah lembar pemeriksaan gingivitis, lembar informed consent, masker, sarung tangan medis, kaca mulut, nierbeken, alat tulis berupa pulpen, dan kamera handphone.

Peneliti terlebih dahulu memberikan surat izin dari pihak RSGM Unsrat ke bagian Periodonsia, kemudian diperlihatkan kepada operator yang akan mengerjakan pasien skeling. Peneliti menjelaskan tujuan penelitian kepada calon responden yang akan menjadi sampel dan ditanyakan kesediannya untuk menjadi responden dalam penelitian dengan memberikan informed concent. Sebelum tindakan skeling, peneliti melakukan pemeriksaan pada gingiva responden dengan menggunakan MGI. Dua hari pasca tindakan skeling, peneliti melakukan kembali pemeriksaan pada gingiva responden dengan menggunakan MGI untuk melihat kondisi gingivitisnya membaik atau tidak.

Data penelitian ini diproses dengan editing, coding, dan entry dan dianalisis menggunakan program aplikasi komputer. Analisis perubahan gingivitis sebelum skeling dan setelah skeling menggunakan MGI di RSGM Unsrat menggunakan uji Paired Sample T-Test.

\section{HASIL PENELITIAN}

Penelitian ini dilakukan di Rumah Sakit Penelitian dilaksanakan di Rumah Sakit Gigi dan Mulut Universitas Sam Ratulangi (RSGM Unsrat) berlokasi di pusat kota Manado Jl. Dr. Sutomo nomor 3, kelurahan Pinaesaan, kecamatan Wenang, provinsi Sulawesi Utara. Rumah Sakit Gigi dan Mulut Unsrat dikelola oleh Universitas Sam Ratulangi yang merupakan tempat Pendidikan Profesi Dokter Gigi. Rumah Sakit Gigi dan Mulut Unsrat menyediakan berbagai macam pelayanan seperti pembersihan karang gigi, pencabutan gigi, penambalan gigi, pembuatan gigi palsu, dan lainlain yang ditangani oleh mahasiswa co-ass dibawah bimbingan instruktur dokter gigi yang merupakan dosen Universitas Sam Ratulangi serta tenaga dokter gigi anggota Persatuan Dokter Gigi Indonesia cabang Sulawesi Utara.

Dari 30 responden yang dilakukan penelitian, jumlah responden yang berjenis kelamin laki-laki sama besar dengan jumlah responden yang berjenis kelamin perempuan, yaitu masing-masing sebesar 15 orang $(50,0 \%)$.

Gambar 1 menunjukkan karakteristik responden berdasarkan usia. Dari 30 responden yang didapatkan, responden yang berusia 17-25 tahun merupakan jumlah responden terbanyak yaitu sebanyak 18 orang $(60,0 \%)$ dan jumlah responden yang paling sedikit berusia 36-45 tahun yaitu sebanyak 4 orang $(13,3 \%)$. 


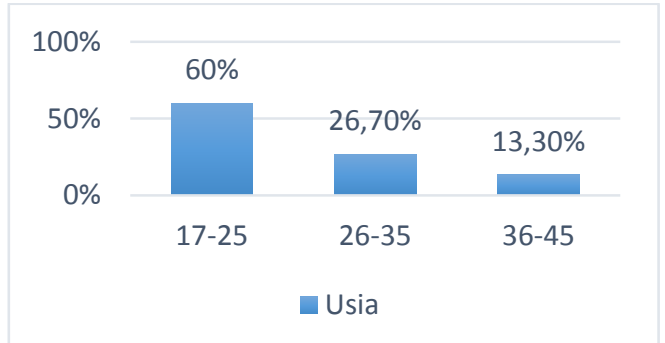

Gambar 1. Distribusi karakteristik responden berdasarkan usia

Gambar 2 menunjukkan kriteria gingivitis sebelum skeling. Responden yang didapati paling banyak mengalami gingivitis sedang terbanyak sebanyak $70,0 \%$ dan jumlah responden paling sedikit yang mengalami gingivitis parah yaitu sebanyak $6,7 \%$, sedangkan kriteria gingivitis dua hari pasca skeling responden yang mengalami gingivitis ringan maupun gingivitis sedang yaitu $50,0 \%$.

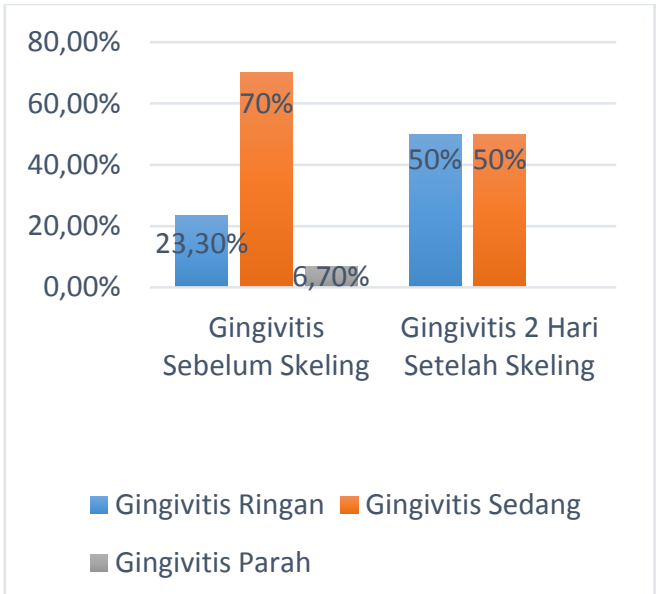

Gambar 2. Grafik distribusi kriteria gingivitis sebelum skeling dan dua hari pasca skeling

Gambar 3 menunjukkan kriteria gingivitis sebelum skeling berdasarkan jenis kelamin. Dari 30 responden yang dilakukan penelitian, responden dengan jumlah terbanyak terjadi pada laki-laki dengan keadaan gingivitis sedang sebesar 73,4\% .

Gambar 4 menunjukkan kriteria gingivitis dua hari pasca skeling berdasarkan jenis kelamin. Gingivitis ringan pada perempuan paling banyak terjadi sebesar $60 \%$ dan paling sedikit terdapat pada perempuan yang mengalami gingivitis sedang sebesar $40,0 \%$.

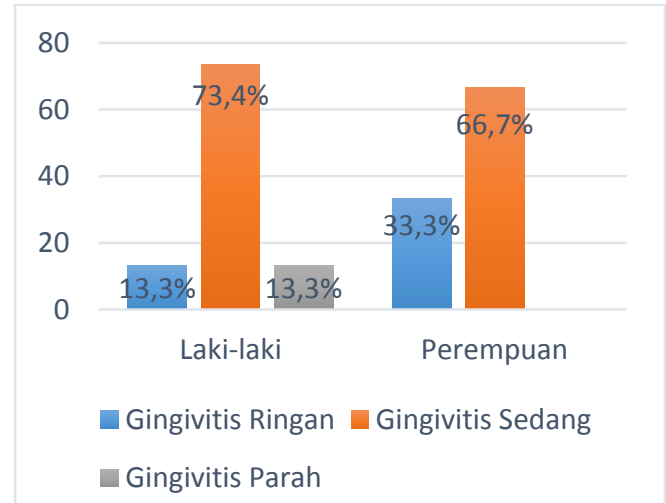

Gambar 3. Grafik distribusi kriteria gingivitis sebelum skeling berdasarkan karakteristik jenis kelamin

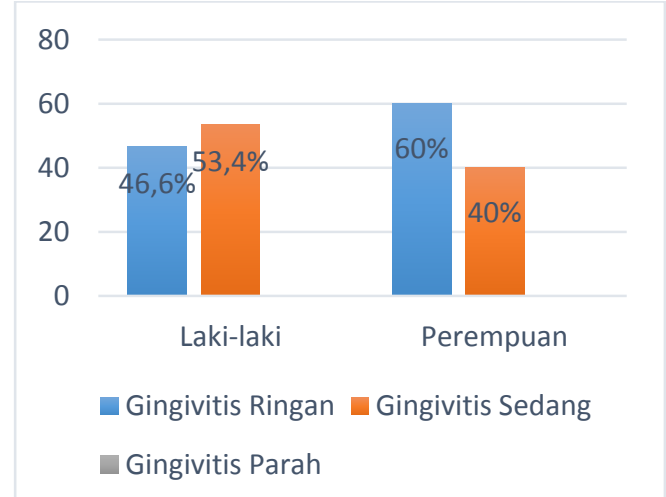

Gambar 4. Grafik distribusi kriteria gingivitis dua hari pasca skeling berdasarkan karakteristik jenis kelamin

Gambar 5 menunjukkan bahwa pada usia 36-45 tahun semua responden mengalami gingivitis sedang dan responden pada usia 17-25 tahun sebesar $66,6 \%$ dengan kriteria gingivitis sedang.

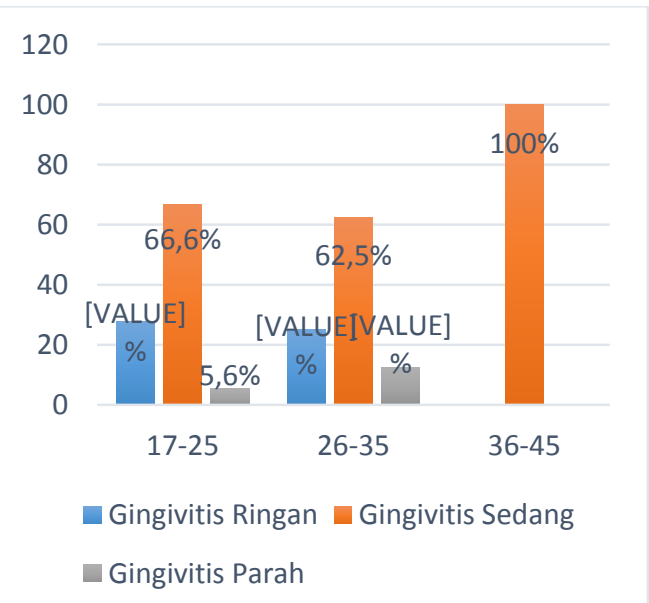

Gambar 5. Grafik distribusi kriteria gingivitis sebelum skeling berdasarkan karakteristik usia 
Gambar 6 menunjukkan kriteria gingivitis dua hari pasca skeling berdasarkan usia. Responden pada usia 17-25 tahun yang mengalami gingivitis ringan sebesar $77,8 \%$ dan pada semua responden usia 3645 tahun masih dengan kriteria gingivitis sedang.

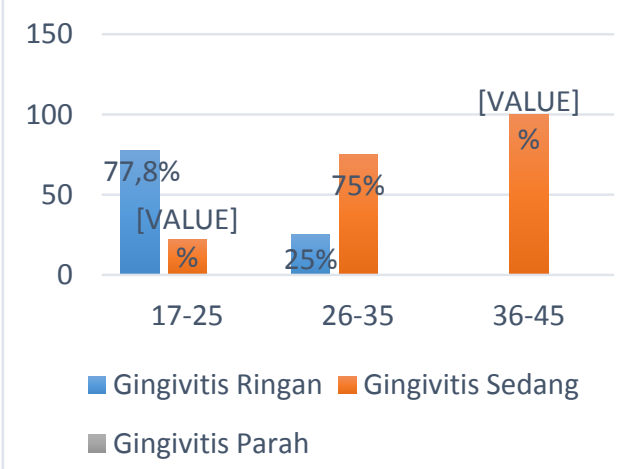

Gambar 6. Grafik distribusi kriteria gingivitis dua hari pasca skeling berdasarkan karakteristik usia

Berdasarkan hasil uji paired samples $t$ test di program aplikasi komputer didapatkan nilai $\mathrm{p}=0,000$ yang menunjukkan adanya perubahan bermakna sebelum skeling dan dua hari pasca dilakukan skeling, yang berarti tindakan skeling efektif terhadap perawatan gingivitis.

\section{BAHASAN}

Hasil penelitian yang dilakukan di RSGM Unsrat mendapatkan sebanyak 30 responden dengan jumlah kedua jenis kelamin sama banyak. Hal ini dapat disebabkan karena laki-laki kurang menjaga kebersihan rongga mulutnya, sedangkan perempuan walaupun sering menjaga kebersihan rongga mulutnya tetapi lebih rentan terhadap penyakit periodontal karena dipengaruhi oleh faktor hormon estrogen dan progesteron. Penelitian yang dilakukan Homata et al ${ }^{12}$ di Yunani tentang perbedaan jenis kelamin pada status kesehatan gigi dan mulut dan perilaku kesehatan gigi dan mulut pada mahasiswa kedokteran gigi yang menyatakan bahwa laki-laki dan perempuan memiliki resiko yang sama terhadap penyakit periodontal, sehingga baik laki-laki maupun perempuan sama-sama membutuhkan perawatan kese- hatan gigi dan mulut, misalnya tindakan skeling. ${ }^{12}$

Kelompok usia terbanyak yang melakukan tindakan skeling terdapat pada usia 17-25 tahun berjumlah 18 orang (60\%) (Gambar 1). Hal ini menunjukkan bahwa kelompok remaja akhir mempunyai kebutuhan akan perawatan kesehatan gigi dan mulut yang didasarkan gejala awal dari kelainan jaringan gingiva, sedangkan pada usia yang lebih lanjut, rendahnya permintaan akan perawatan gigi lebih berkurang karena motivasi merawat diri yang juga berkurang. ${ }^{13,14}$ Penelitian yang dilakukan oleh Anggraini ${ }^{13}$ tentang gambaran status kebersihan rongga mulut dan status gingiva pasien RSGM Universitas Jember mendapatkan sampel terbanyak yang berkunjung ke RSGM ialah kelompok remaja akhir.

Hasil penelitian menunjukkan bahwa gingivitis sebelum skeling banyak terjadi pada kriteria gingivitis sedang sebanyak 21 orang $(70 \%)$ dan yang mengalami gingivitis paling sedikit terjadi pada gingivitis parah sebanyak 2 orang $(6,70 \%)$, sedangkan dua hari pasca skeling didapatkan adanya penurunan skor MGI dimana gingivitis ringan dan sedang menjadi sama banyak yaitu masing-masing 15 orang (50\%) (Gambar 2). Dilakukan pemeriksaan dua hari pasca tindakan skeling karena penyembuhan gingivitis merupakan berhentinya proses inflamasi pada gingiva yang dapat dilihat secara klinis dan laboratorik. Secara klinis penyembuhan gingivitis dapat dilihat secara visual dengan mengamati perubahan gingiva dari adanya inflamasi menjadi normal yang dapat dilihat mulai dari dua hari pasca skeling. Hal ini juga didukung oleh penelitian sebelumnya tentang efektivitas skeling terhadap penyakit periodontal yang menyatakan bahwa tindakan skeling dapat membantu penyembuhan penyakit periodontal khususnya gingivitis karena skeling mengeliminasikan bakteri yang terdapat pada plak dan kalkuklus yang menjadi penyebab gingivitis, sehingga keparahan gingivitis dapat menurun. ${ }^{15,16}$

Hasil penelitian menunjukkan sebelum skeling, gingivitis tertinggi didapatkan pada 
responden jenis kelamin laki-laki dengan kriteria gingivitis sedang sebanyak 11 orang $(73,4 \%)$ dan responden dengan jenis kelamin perempuan yang mengalami gingivitis terbanyak yaitu gingivitis sedang sebesar 10 orang $(66,7 \%)$ (Gambar 3). Hal ini dapat terjadi karena perempuan cenderung lebih mengutamakan kebersihan dan kesehatan gigi dan mulutnya dibandingkan laki-laki. Penelitian yang dilakukan oleh Nur $^{17}$ di Surabaya tentang keparahan gingivitis pada pasien poli puskesmas Sawahan Surabaya mendapatkan sampel pada laki-laki menunjukkan gingivitis yang lebih tinggi dari pada sampel perempuan.

Hasil penelitian memperlihatkan dua hari pasca skeling pada responden berjenis kelamin laki-laki yang mengalami gingivitis terbanyak yaitu gingivitis sedang sebanyak 8 orang $(53,4 \%)$ dan pada responden berjenis kelamin perempuan yang mengalami gingivitis terbanyak menjadi gingivitis ringan yaitu sebanyak 9 orang $(60,0 \%)$ (Gambar 4). Penelitian ini menunjukkan dua hari pasca skeling didapatkan penurunan skor MGI yang berarti skeling efektif dalam penyembuhan gingivitis walaupun pada responden berjenis kelamin perempuan penyembuhan gingivitis memakan waktu lebih lama karena kesehatan jaringan periodontal pada perempuan dipengaruhi oleh fluktuasi hormon estrogen dan progesteron yang dapat berpengaruh pada proses pemulihan gingiva pasca skeling. ${ }^{18,19}$

Pada penelitian ini gingivitis sebelum skeling yang paling banyak muncul terjadi pada usia 17-25 tahun sebanyak 18 orang dengan gingivitis sedang sebanyak 12 orang $(66,6 \%)$ (Gambar 5). Hal ini terjadi karena usia remaja akhir cenderung mengonsumsi makanan rendah vitamin $\mathrm{C}$ dan rendah kalsium, namun tinggi konsumsi minuman berkarbonasi, sehingga responden berusia 17-25 tahun banyak yang menderita defisiensi vitamin $\mathrm{C}$ dan kalsium yang akan memengaruhi kesehatan jaringan periodontalnya. Hasil penelitian yang dilakukan oleh Tadjoedin et $\mathrm{al}^{20}$ di Jakarta menyatakan bahwa kelompok usia remaja akhir yang berusia 17-25 tahun mempunyai prevalensi gingivitis yang lebih tinggi.

Hasil penelitian menunjukkan pada pemeriksaan dua hari pasca skeling, gingivitis paling banyak muncul terjadi pula pada usia 17-25 tahun dengan gingivitis ringan sebanyak 14 orang $(77,8 \%)$, sedangkan gingivitis pada usia 3645 tahun sebanyak 4 orang (100\%) masih sama dengan gingivitis sebelum skeling yaitu masih berada di kriteria gingivitis sedang tetapi telah mengalami penurunan skor MGI menjadi lebih rendah dari sebelum skeling (Gambar 6). Pada usia 1725 tahun gingivitis ringan masih banyak terjadi pada dua hari pasca skeling, tetapi terdapat penurunan kriteria gingivitis ringan dari kriteria gingivitis sedang saat sebelum skeling. Hal ini dapat terjadi karena pada usia 17-25 tahun jaringan pada tubuh lebih mudah dan lebih cepat untuk beregenerasi, sedangkan seiring dengan bertambahnya usia tubuh manusia mengalami perubahan degeneratif pada jaringan tubuh sehingga proses regenerasi tidak berjalan dengan cepat. Faktor ini menyebabkan pada usia 36-45 tahun gingivitis tetap pada kriteria yang sama namun terjadi penurunan skor MGI yang berarti tetap terdapat efektivitas skeling terhadap gingivitis. $^{21}$

Hasil uji paired samples t-test sebelum skeling dan dua hari pasca skeling menunjukkan perubahan bermakna, yang berarti tindakan skeling efektif dalam perawatan jaringan periodontal khususnya pada gingivitis karena faktor lokal penyebab terjadinya gingivitis seperti bakteri plak dan kalkulus yang menempel pada supragingiva dan subgingiva dapat tereliminasi. Tindakan skeling dilakukan karena dapat mengurangi peran mikroba dan faktor-faktor yang berperan dalam perkembangan penyakit gingivitis, serta mencegah perkembangan periodontitis. Hasil akhir dari tindakan skeling menghentikan proses perkembangan penyakit dan mengembalikan kondisi gingiva pada keadaan sehat. ${ }^{22}$ Penelitian ini didukung oleh penelitian sebelumnya tentang efektivitas skeling terhadap penyakit periodontal yang menyatakan bahwa skeling sangat 
efektif dalam penanganan penyakit periodontal khususnya penanganan gingivitis. ${ }^{16}$

\section{SIMPULAN}

Berdasarkan hasil penelitian yang dilakukan di RSGM Unsrat dapat disimpulkan bahwa tindakan skeling efektif terha-dap perawatan gingivitis berdasarkan peni-laian menggunakan modified gingival index.

Diharapkan penelitian lanjut dengan waktu kontrol yang lebih panjang atau lebih dari dua hari sehingga proses perbaikan jaringan periodontal dapat lebih baik.

\section{DAFTAR PUSTAKA}

1. Astuti LA. Alternatif splinting pada kegoyangan gigi akibat penyakit periodontal. J As-Syifaa 2015;7(2); 209-18.

2. Sunarto H. Plak sebagai penyebab utama peradangan jaringan periodontal. Jakarta: FKUI; 2014.

3. Krismariono A. Prinsip-prinsip dasar skeling dan root planing dalam perawatan periodontal. Perio J. 2009;1(1)30-4.

4. Direktorat Jendral Bina Upaya Kesehatan. Pedoman usaha kesehatan gigi sekolah. Jakarta: Kemenkes RI, 2012; p. 5-6.

5. Badan Penelitian dan Pengembangan Kesehatan. Hasil utama Riskesdas 2013. Jakarta: Kemenkes RI, 2013; p. 110-1.

6. Badan Penelitian dan Pengembangan Kesehatan. Hasil utama Riskesdas 2018. Jakarta: Kemenkes RI, 2018; p. 94.

7. Wahyukundari MA. Perbedaan kadar matrix metalloproteinase- 8 pasca scaling dan pemberian tetrasiklin pada penderita periodontitis kronis. J PDGI 2009; 58(1):1-6.

8. Diah, Widodorini T, Nugraheni NE. Perbedaan angka kejadian gingivitis antara usia pra-pubertas dan pubertas di kota Malang. E-Proden J Dent 2018;2(1): $108-15$.

9. Kasiha HE, Kawengian SES, Juliatri. Gambaran tingkat pengetahuan ibu hamil tentang gingivitis di puskesmas Kakaskasen Tomohon. eG. 2017;5(2): 166-71.

10. Octavia M, Soeroso Y, Kemal Y. Efek klinis pasca skeling dan penghalusan akar kasus periodontitis kronis poket 4-6 mm. Dentika Dental Journal. 2015;18(3):211-7.
11. Newman MG, Takei HH, Carranza FA. Clinical Periodontology (9th ed). Philadelphia: WB Saunder Co, 2002; . p.16-32, 79-81, 269-77, 631.

12. Homata EM, Kounari HK, Margaritis V. Gender differences in oral health status and behavior of Greek dental student: a meta-analysis of 1981, 2000, amd 2010 data. J Int Soc Prev Comm Dent 2016; 6(1);60-8.

13. Anggraini CW, Aris $M$, Pujiastuti $P$. Gambaran status kebersihan rongga mulut dan status gingiva. Jember Pustaka Kes J. 2015;4(3);525-32.

14. Tadjoedin FM, Fitri AH, Kuswandani SO, Sulijaya B, Soeroso Y. The correlation between age and periodontal diseases. Journal of International Dental and Medical Research. 2017;10(2);327-32.

15. Puspaningrum EF, Hendari R, Mujayanto R. Ekstrak cymbopogon citratus dan eugenia aromaticum efektif untuk penyembuhan gingivitis. Odonto Dental J. 2015:2(2);47-51.

16. Perry DA, Schmid MO, Takei HH. Phase I periodontal therapy. In: Newman, Takei H, Klokkevold PR, Carranza FA, editors. Clinical periodontology (10th ed). Philadelphia: WB Saunder Co, 2006; p. 722-880.

17. Nur MR, Krismariono A, Rubianto $M$. Keparahan gingivitis pada pasien poli puskesmas Sawahan Surabaya tahun 2016 menggunakan Gingival Indeks (GI). Surabaya: Universitas Airlangga; 2016; p. 15-20.

18. Mitchell L, Mitchell DA, McCaul L. Kedokteran Gigi Klinik (semua bidang kedokteran gigi) (5th ed). Jakarta: EGC, 2014; p. 197.

19. Loannidou E. The sex and gender intersection in chronic periodontitis. Front Pub Health. 2017;5(5);189

20. Aljehani YA. Risk factors of periodontal disease: review of the literature. Int $\mathbf{J}$ Dent. 2014;2014:182513.

21. Wijaya NPAP, Ulfah N, Krismariono A. Keparahan gingivitis pada pasien poli gigi puskesmas mulyorejo tahun 2016 menggunakan gingiva indeks. Surabaya: Universitas Airlangga; 2016.

22. Zulfa L, Mustaqimah DN. Terapi periodontal non-bedah. Makassar: Universitas Hasanuddin; 2011. 